\title{
Financial Transaction Tax as an Instrument for Banking Sector Regulation in the EU
}

\author{
Marija Koḷesnika ${ }^{1}$, Inna Dovladbekova ${ }^{2},{ }^{1-2}$ Rīgas Stradina Universitāte
}

\begin{abstract}
The aim of study "Financial Transaction Tax as an Instrument for Banking Sector Regulation in the EU" is by analyzing scientific literature, as well as statistical data and theoretical framework, to explore the impact of financial transaction tax on banking business in the $\mathrm{EU}$ and to offer suggestions for the improvement of the European Union's bank regulatory system. Section I provides an introduction to the necessity of implementation of financial transaction tax as an instrument of banking sector regulation. Section II presents theoretical analysis of regulatory policy of the financial sector. Section III illustrates the financial transaction tax performance analysis within the European Union. Section IV outlines the opportunities for improvement of banking sector regulation and concludes the article.
\end{abstract}

Keywords: financial transaction tax, European Commission, European Union, financial sector, banking business, financial crisis.

\section{INTRODUCTION}

Each transaction has its own tax implications, whether it is a purchase, sale, refinancing, or initial public offering. Successful economic growth requires currency, money, capital, securities and market expansion. Financial market is an important indicator of foreign investment inflow to the country as operations in the developed financial markets give opportunities to minimize financial risks that exist even in advanced countries.

In the context of economic and financial crisis, it is more and more commonly accepted that financial sector should make a fairer contribution, as this sector has been under-taxed due to the exemption from VAT of most financial services. That is the reason why the term of financial transaction tax (FTT) is used in the international practice, the main objectives of which are to ensure that financial institutions make a fair contribution in covering costs of the crisis and to avoid fragmentation of the internal market with regard to financial transactions.

The financial transaction tax is defined as a tax levied on financial transactions, usually at a very low rate. A financial transaction is an exchange of financial instruments between banks or other financial institutions, relevant financial instruments comprise securities, bonds, equities and derivatives. The financial transaction tax is levied on certain transactions that are acknowledged as taxable rather than individual financial institutions.

In 2014 financial transaction tax would be a part of the EU financial sector reform, which aims to protect EU taxpayers from saving ailing banks in the case of a new financial crisis. The financial transaction tax will be part of new own resources.

The tax supporters believe that it will reduce the number of speculative transactions. This actually points to the problem addressed in the present study, which is the fact that banks should take the burden of the financial crisis, in that way helping countries affected by euro zone debt crisis. It is planned to collect billions of euro to the EU budget, however, these costs are likely to make banking services more expensive to residents and businesses. This makes the study of financial transaction tax as an instrument for banking sector regulation in the EU a topical problem, since increasing the financial transaction costs, not only the market structure may change, but also the matter of speculative nature growth in businesses becomes questionable, at the same time, consumer spending power could be affected as well.

The aim of the study is by analyzing scientific literature, as well as statistical data and theoretical framework, to explore the impact of financial transaction tax on the banking business in the EU and to offer suggestions for the improvement of the European Union's bank regulatory system. The object of study is a financial transaction tax as an instrument of regulation of the financial market, its subject is the influence of FTT on the banking sector in the EU.

The study is conducted adopting both theoretical and empirical approaches, in that way considering the theoretical concepts of the principles of the financial supervision mechanism, its functions, and types; the role of banks in it, as well as the impact of the taxation policy of the financial sector on banking. Financial transaction tax is defined as an instrument of financial sector regulatory policy. As FTT is not a newly implemented tax, it is important to base a research on the existing past experience. The UK and Sweden are the countries most frequently analyzed with regard to their experience with financial transaction taxes. Although the UK had no implementation issues associated with stamp duty that is used nowadays, Sweden, on the other hand, refused the FTT model when it was proven that it is an unsatisfactory source of income with a wide range of adverse side effects. Taking into consideration both negative and positive experience within the EU, it is very important to heed that newly announced FTT will replace all existing similar fees, which, in fact, makes it confusing for most Member States.

The authors investigate both Sweden's and the UK case studies, and perform analysis of the future EU financial transaction tax mechanism and potential risks associated with its implementation using the fundamental analysis of macroeconomic indicators, as well as multifunctional regression analysis method to predict individual financial market movements and to estimate the revenue from a financial transaction tax. The study period of the Swedish case is from 1982 to 1992, whereas the UK case was carried out from 1986 to 2012, finally, the EU FTT analysis was done in the time period from 2007 to 2012 with a future prediction.

Designated qualitative research is based on experts' surveys, conducted by the authors. Six different expert opinions on the 
positive and negative features of the EU financial transaction tax, as well as on the functioning of financial transaction taxes in other countries studied have been used.

\section{THEORETICAL ANALYSIS OF REGULATORY POLICY OF THE FINANCIAL SECTOR}

\section{A. Historical development of financial transaction tax}

The financial transaction tax is not an entirely new phenomenon as it is evidenced by a few studies that have already been done in this area. For example, Sony Kapoor, David Hillman and Stephen Spratt in their study "Implementing a Currency Transaction Development Levy" [7] state that dating back to 1694 the first registered transaction charges had a form of a state tax applied by the London Stock Exchange. The tax share was paid by the buyer, and the purchase and sale document was sealed by an official stamp that was required to draw up the purchase transaction.

During the Great Depression in 1936 John Maynard Keynes promoted the wider use of a financial transaction tax [8]. He proposed to charge a small transaction tax on the Wall Street transactions in the United States, and claimed that the speculation level is too high caused by ill-considered actions of financial traders. Keynes was concerned about the proportional distribution of financial speculators in the market, and the chances of their dominance if they remain unchecked. In 1936, when Keynes first proposed a financial transaction tax, he wrote, "Speculators may do no harm as bubbles on a steady stream of enterprise. But the situation is serious when enterprise becomes the bubble on a whirlpool of speculation" [8]. Protection of businesses from the conversion bubble was also an intended purpose of the 1972 Tobin tax. Tobin tax, which was suggested by the Nobel Prize Laureate James Tobin in 1972, was originally defined as a tax on all foreign exchange spot transactions of $0.5 \%$ from the transactions value. The tax was imposed on short-term currency conversions. It played an important role in 1971, the year when the United States was no longer able to convert dollars, i.e. change them to gold according to the Bretton Woods system [9]. Faith in the dollar depreciated, and the Bretton Woods system collapsed. The Tobin tax became an instrument for the protection of foreign exchange. Its variations in the 1994 were used during the Mexican financial crisis in order to protect the national currency, as well as in other countries, but not in every country the tax became a success story [9].

\section{B. Financial transaction tax as an instrument of financial sector regulatory policy}

In the context of the economic and financial crisis, it is more and more commonly accepted that the financial sector should make a fairer contribution; this sector has been undertaxed to date given the exemption from VAT of most financial services. That is the reason why in the international practice the term financial transaction tax is used, the main objectives of which are to ensure that financial institutions make a fair contribution in covering costs of the crisis and to avoid fragmentation in the internal market with regard to financial transactions.

The study by International Monetary Fund "Securities Transaction Taxes and Financial Markets" describes FTT as a tax levied on financial transactions, usually at a very low rate [6].
Financial transaction is seen as an exchange of financial instruments between banks or other financial institutions. Relevant financial instruments comprise securities, bonds, equities and derivatives. The financial transaction tax is levied on certain transactions that are recognized as taxable instead of individual financial institutions.

This tax does not apply to financial transactions carried out by individuals or companies, such as insurance contracts, mortgage loans, credit card loans and businesses - transactions typically undertaken by retail banks in their relations with private households or businesses, except when they relate to the sale or purchase of bonds or shares [1].

Financial transaction tax is featured as a tax applied to financial transactions, usually at a very low rate.

There are 3 core objectives the FTT should fulfill. First, it will strengthen the Single Market by reducing the number of divergent national approaches to financial transaction taxation. Secondly, it will ensure that the financial sector makes a fair and substantial contribution to public revenues. Finally, the FTT will support regulatory measures in encouraging the financial sector to engage in more responsible activities, geared towards the real economy.

In the case of a financial transaction tax at the EU level, it should be noted that a fair share of the EU budget is devoted to growth and jobs, as well as to addressing global challenges such as development and climate change.

\section{FINANCIAL TRANSACTION TAX PERFORMANCE ANALYSIS WITHIN THE EUROPEAN UNION}

The countries selected for empirical study are Sweden, the United Kingdom, and the European Union as a whole region. By means of statistical analysis the shortcomings as well as positive features of financial transaction tax enforcement are established and acknowledged. The UK had no problems with the implementation and enforcement of financial transaction tax. Sweden, on the other hand, refused this kind of fee, when it was proven that it is an unsatisfactory source of income with large negative effects [2]. The authors investigate both Sweden's and UK case studies, and perform analysis of the future EU financial transaction tax mechanism, and potential risks associated with its implementation using the fundamental analysis of macroeconomic indicators, as well as multifunctional regression analysis method to predict individual financial market movements and to estimate the revenue of a financial transaction tax.

\section{A. Swedish case of FTT implementation}

The Swedish FTT was introduced in 1984 and abolished in 1991. Its size and scope were changed on several occasions. From 1984 until 1989, it was applied primarily to transactions in stocks and stock based derivatives. From 1989, transactions in fixed-income securities - primarily bonds and bills - and derivatives based on those securities were included as well [10].

As Campbell J. Y. mentions in his study "International Experiences with Securities Transaction Taxes", due to political focus on wages in the domestic financial sector, the tax was levied on Swedish brokerage services. Brokers generally made a lot of money at that time and all transactions of a substantial size carried out in Sweden depended on such services. This meant that the tax did not apply to small 
transactions where a broker was not involved. It also meant that transactions in Swedish securities via non-Swedish brokers outside of Sweden were not made subject to taxation [2]. In that way it was relatively easy to avoid the charge.

Figure 1 shows the changes in turnover on Stockholm exchange during the FTT enforcement. In the first phase, stock transactions from 1984 were taxed at $0.5 \%$ on both purchase and sale (1\% per return deal). Stock options were taxed at $1 \%$. In the first two years of these rates being applied, the effects were limited. Revenues were disappointing. Therefore, the rates were doubled in 1986, raising the tax on stock transactions to $1 \%$. This increase quite cardinally influenced market behavior. In order to avoid the tax, foreign investors shifted large parts of their transactions in Swedish stocks to non-Swedish brokers that were based outside Sweden. Around $60 \%$ of the trading volume in the most actively traded Swedish stock classes eventually moved to London. Swedish investors, on the other hand, could not avoid the tax that easily. Some of them established offshore domiciles or companies to use non-Swedish brokers, but that was an expensive maneuver. The main reaction from Swedish actors was instead dampening of transaction volumes. Overall, the 1986 rate increase did not reduce total trading volumes in Swedish stocks by much, but rather pushed trading from Stockholm to London - meaning that tax revenues in Sweden remained very small [2].

Later on some additional taxes on fixed-income securities and derivatives were added. The key categories were government bonds and bills. The tax rates varied, but the maximum rate was no higher than $0.15 \%$ of the underlying notional or cash amount. For bills and bonds, longer maturities meant higher tax rates. While maturities of more than five years were taxed at $0.015 \%$, maturities under 90 days were taxed at $0.001 \%$. This fixed-income addition had a very radical impact on market behavior. In the first week, for example, trading in bonds fell by around $85 \%$ and trading in futures on bills and bonds by as much as about $98 \%$. Consequently, revenues turned out to be insufficient. The reason for the market collapse was not emigration of the trading abroad, but rather the fact that there were excellent fixed-income substitutes in the Swedish market to the instruments that were made subject to taxation. In order to avoid the tax, investors very easily and inexpensively moved from bills and bonds into non-taxed instruments like debentures, variable-rate notes, forward-rate agreements and swaps.

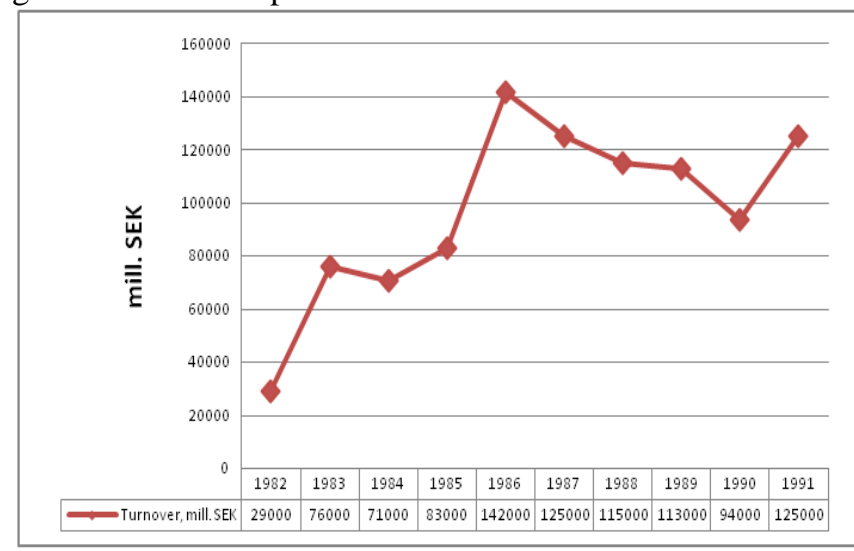

Fig. 1 Turnover Stockholm Stock Exchange

[elaboarated by authors based on [3]]
Because of the bad performance of the Swedish FTT in most markets, it was phased-out and eliminated in 1990-1991 [13].There is a broad agreement in the financial literature that the tax was a failure. Mainly it is concluded that the tax "failed due to a bad tax design and the resulting migration of trading volume".

\section{B. UK financial transaction tax}

The securities transaction tax in the United Kingdom is known as "stamp duty." As the name suggests, stamp duty began as a tax on the transfer of a financial instrument from one owner to another, a transfer which could only be made legally effective by an official stamp applied to the instrument. Thus stamp duty is a tax on the registration of ownership of a financial asset. In 1986 the UK government closed certain loopholes in the application of stamp duty by introducing a "stamp duty reserve tax" (SDRT), which substitutes stamp duty itself and is paid at the same rate [2].

Stamp duty applies to transactions in ordinary shares and in the assets convertible to shares such as convertible unsecured loan stock while the conversion option is still exercisable. Futures and options transactions are not taxable, but the exercise of an option is treated as a purchase of ordinary shares at the exercise price and is therefore taxable. Transactions in the shares of investment trusts are taxable in the ordinary way, as are the transactions carried out by the managers of investment trusts. Purchases and redemptions of units in unit trusts (open-end funds, in U.S. terminology) are taxed as if they were transactions in the underlying shares held by the trust. Transactions in fixed-income securities, such as corporate and government bonds are not taxable [14].

Stamp duty applies to both primary and secondary market transactions. When new shares are issued, the issuer pays the tax, whereas in the secondary market transactions the purchaser pays the tax. Corporate repurchases of shares are also taxable.

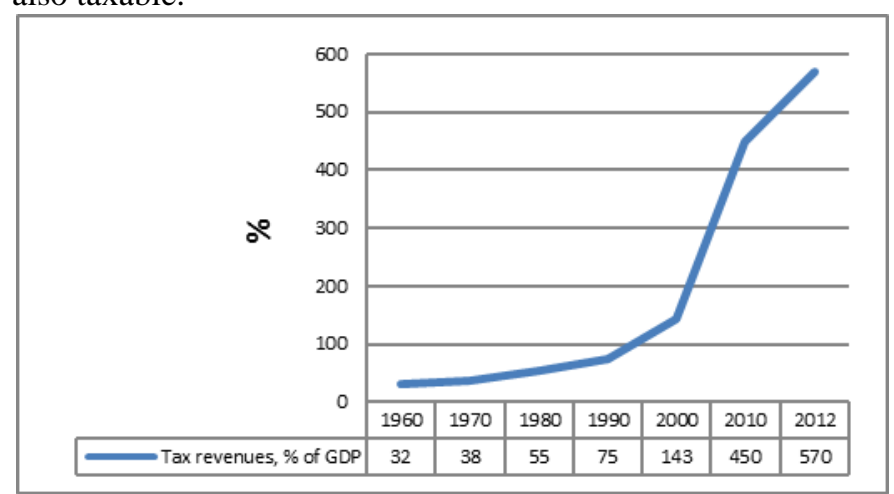

Fig. 2 Tax revenues, \% of GDP [elaborated by authors based on [4]]

There are a few exemptions from stamp duty. Registered charities are exempt, as are market makers registered by the London Stock Exchange when they trade in the securities for which they make a market and member firms of the London International Futures and Options Exchange (LIFFE) when they trade to hedge equity options positions or to meet delivery obligations following the exercise of equity options.

Figure 2 demonstrates the opposite result of FTT implementation, by increasing tax revenues over the years. The rate of stamp duty has varied over the years. In August 1963 the rate was lowered from 2 percent to 1 percent, 
increasing to 2 percent in May 1974, falling again to 1 percent in April 1984 and to 0.5 percent in October 1986. In its 1990 budget the British government announced its intention to abolish stamp duty altogether when the London Stock Exchange's Taurus system for electronic settlement came online. With the collapse of the Taurus development project in the spring of 1993, the future of stamp duty remained at rate $0.5 \%$ [2].

\section{EU financial transaction tax}

Elsewhere in the world there are several types of financial transactions, thus, on the basis of well-known Swedish and British models, the authors analyze possible EU financial transaction tax scenarios and initial analysis of the banking sector in the European Union.

In order to understand how to put into action the financial transaction tax on bank transactions, the authors examine an example of an inter-bank transaction through SWIFT system (Society for Worldwide Interbank Financial Telecommunication, or Interbank Financial Telecommunication company which is a bank-based international organization that provides wholesale financial messaging services using telecommunications network) [5].

The basis is the recognition that the Bank Austria Vienna is sending currency U.S. dollars to ABN Amro Bank in Amsterdam. Figure 3 reflects that money flow comes from the bank, which is located in Austria, that handles their dollars on the accounts of the correspondent bank Chase Manhattan Bank in New York, while the recipient holds its U.S. dollar account with another correspondent - ABN Amro Bank in New York. In order to perform this type of transaction, the Sender sends the order to the correspondent bank, which in turn transmits the beneficiary correspondent credited to the final recipient. Thus, tax will be charged 3 times as long as the money reaches the final beneficiary.

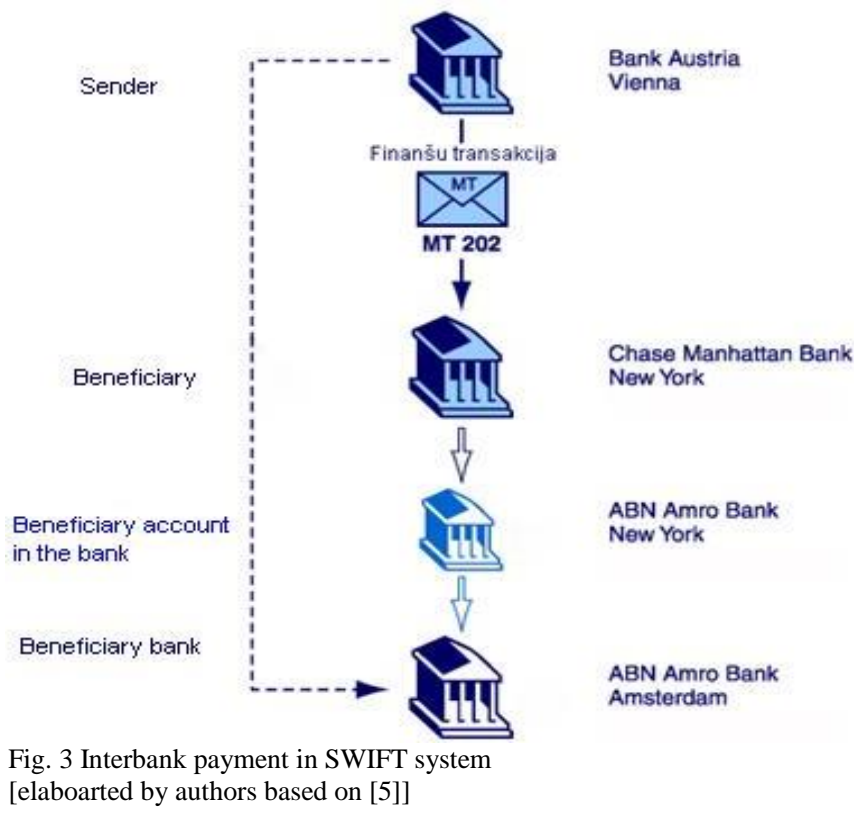

This example is a typical reflection of inter-bank transactions. This type of transfer takes place on a daily basis in a wide range of currencies, sometimes expanding the number of intermediaries and clearing agents and brokers who process financial business orders [12].
In order to evaluate the risks of FTT implementation, the authors perform analysis of the future EU financial transaction tax mechanism, and potential risks associated with its implementation using the fundamental analysis of macroeconomic indicators, as well as multifunctional regression analysis method to predict individual financial market movements and to estimate the revenue of a financial transaction tax.

In this particular model, the authors assumed the capacity of the EU stock market as a variable and such indicators as GDP (in millions of euro), market capitalization (in million euro) and inflation (in \%) as independent variables.

Due to limited access to the EU financial markets data, derivatives and securities market volumes were not included in the model and time frame was diminished to 2007-2014, source: Foreign direct investment statistics, EUROSTAT.

As a starting point of the analysis, the authors raised a null hypothesis that GDP, market capitalization and inflation have no impact on the stock market volumes. Multifunctional regression analysis found to be statistically significant with a probability of $95 \%$, which is proven due to $t$ stat $>t$ critical $=>t$, assuming that $\mathrm{t}$ critical $=1.96$ and assumed elements $\Rightarrow>$

- $\mathrm{GDP}=-2.029332901$

- Market capitalization $=2.038713975$

- Inflation = 2.440952124

Multivariate correlation indicates a close link between the studied variables, which is 0.894447 . Multivariate multiple coefficient of determination is the square of the correlation coefficient. It shows the proportion of variance explained by the independent variables; in this case it is $80 \%$ or 0.800036 .

The authors have taken into account the above discussed macro-economic data forecasts expressed in millions of euros, so that the regression analysis could predict stock market volumes in year 2013 and 2014, which represents $6,097,124.33$ and 5,967,259.04 respectively. Data shows that the null hypothesis previously put forward has not been proven, as GDP, market capitalization and inflation have an impact on the stock market volumes. The results are shown in Table 1.

TABLE I

RESULTS OF MULTIFUNCTIONAL REGRESSION ANALYSIS [ELABORATED BY AUTHORS BASED ON [11]]

\begin{tabular}{|l|l|l|l|r|}
\hline & $\begin{array}{l}\text { Volumes of } \\
\text { stock market, } \\
\text { mill. EUR }\end{array}$ & $\begin{array}{l}\text { GDP, mill. } \\
\text { EUR }\end{array}$ & $\begin{array}{l}\text { Market } \\
\text { capitalisation, } \\
\text { mill. EUR }\end{array}$ & $\begin{array}{l}\text { Inflation, } \\
\%\end{array}$ \\
\hline 2007 & $17,430,328.00$ & $3,048,691.00$ & $10,640,870.00$ & 0.024 \\
\hline 2008 & $13,960,423.00$ & $3,053,852.00$ & $5,536,790.00$ & 0.037 \\
\hline 2009 & $8,047,727.00$ & $2,996,756.50$ & $7,247,040.00$ & 0.01 \\
\hline 2010 & $8,419,348.00$ & $3,019,323.40$ & $8,086,240.00$ & 0.021 \\
\hline 2011 & $8,270,569.00$ & $3,115,321.70$ & $7,165,810.00$ & 0.031 \\
\hline 2012 & $6,585,771.00$ & $3,138,710.40$ & $7,821,430.00$ & 0.026 \\
\hline 2013 & $6,097,124.33$ & $\mathbf{3 , 1 3 5 , 5 7 1 . 6 9}$ & $\mathbf{8 , 3 5 6 , 9 0 0 . 0 0}$ & $\mathbf{0 . 0 2 3}$ \\
\hline 2014 & $5,967,259.04$ & $\mathbf{3 , 1 1 6 , 7 5 8 . 2 6}$ & $\mathbf{8 , 4 2 7 , 0 9 0 . 0 0}$ & $\mathbf{0 . 0 2 0}$ \\
\hline
\end{tabular}


Thus, the data on market capitalization may be obtained to predict tax revenue from the stock market in the EU, which is reflected in Table 2 and makes 8,356.9 million EUR in 2013 and 8,427.09 million EUR in 2014.

TABLE II

THE PROJECTED REVENUE FROM FTT, BILL. EUR [ELABOARTED BY AUTHOR BASED ON [11]]

\begin{tabular}{|l|l|l|l|l|}
\hline & $\begin{array}{l}\text { Stock market } \\
\text { volumes, mill. } \\
\text { EUR }\end{array}$ & $\begin{array}{l}\text { Market } \\
\text { capitalisation, } \\
\text { mill. EUR }\end{array}$ & $\begin{array}{l}\text { Average } \\
\text { cost of 1 } \\
\text { transaction, } \\
\text { EUR }\end{array}$ & $\begin{array}{l}\text { Predictable } \\
\text { tax revenues, } \\
\text { mill. EUR }\end{array}$ \\
\hline 2013 & $6,097,124.331$ & $8,356.900$ & 1,37 & 356.90 \\
\hline 2014 & $5,967,259.043$ & $8,427.090$ & 1,41 & 427.09 \\
\hline
\end{tabular}

By using the approach of fundamental analysis of macroeconomic indicators that include multifunctional regression analysis, the potential tax revenue from the banking sector might be determined; it will be reflected as losses. According to the law of supply and demand, both banks and companies will search for a way to recover their losses, and there is a high probability that consumers or customers of the banking sector will be the ones to cover the difference.

\section{OPPORTUNITIES FOR IMPROVEMENT OF BANKING SECTOR REGULATION}

The regulation of the banking sector plays a significant role in the financial environment. The exact aim of this chapter is to consider the competent opinion of experts in order to make qualitative research - expert surveys, assessing the positive and negative features of financial transaction tax, as well as opportunities of development of the banking sector regulation.

Experts were chosen from the institutions that have a direct connection to banking and regulation, tax administration and management. The current survey polled British and Swedish, German and Latvian representatives:

- Dr. oec. Oḷegs Jemeljanovs, Chief Economist, International Relations and Protocol Division, Bank of Latvia;

- Jānis Zelmenis, attorney partner at law firm "BDO Zelmenis \& Liberte”, mainly involved in tax legislation issues;

- Dr. oec., prof. Kārlis Ketners, Professor at RTU Customs and Tax Department, Deputy Director-General of the former $S R S$;

- MSc. Intl Business Diana Ledkova, SEB London FX Prime Brokerage Agent;

- MSc. Intl Business Andrejs Nikitins, SEB Stockholm FX/MM /CLS representative, Aarhus University's School of Business;

- Prof. Dr. oec. Matthias Muck, Prof. at Otto-Friedrich University of Bamberg.

The following questions were asked in the survey:

1. Do you agree that increasing financial transaction costs could change market structure and make the nature of business more speculative?

2. Swedish experience with Securities transaction tax in the late 1980's shows that during the first week of the taxation, the volume of bond trading fell by $85 \%$, even though the tax rate on five-year bonds was only $0.003 \%$. In your opinion, could EU proposed rate of $0.01 \%$ for securities cause avoidance of tax and risk of market movement?

3. In your opinion, is it possible that a financial transaction tax could help to contribute to public revenue, which is spent in the public interest, for example to bail out banks if another financial crisis hits the markets?

4. The Commission has proposed that the tax should cover only transactions where financial institutions are involved. The aim is to tax the financial sector, not their clients. Do you think that this will result in increase in price for banking services and consumer purchasing power as well?

5. In your opinion, by introducing FTT, would the EU become a less attractive place for banking business and should the tax be introduced on a global scale, as suggested by the EU representatives on the G-20 Summit?

6. As an expert could you please provide an alternative to FTT in order to enhance financial sector inter alia banking sector regulation within the EU?

Expert opinions on the positive and negative features of the EU financial transaction tax, as well as the functioning of financial transaction taxes in other countries studied were used to investigate the outstanding FTT topic. Solutions for improvement of regulation of banking sector regulations as well as possible risk evaluation of its implementation are brought forward.

Main conclusions are based on FTT actual application, which include the movement of financial institutions into other countries, economic distortions and as well as partial loss of competitiveness.

Firstly, the Swedish case is an evidence of what may be expected when the new Commission proposal is implemented, however, it is questionable. There are too many differences between this case and the present FTT concept. Swedish FTT was much higher for securities and derivatives. The main gaps were in the fixed income instruments that the Commission has avoided in their initial proposal. UK stamp duty is a positive example, which should form the basis for the realization of FTT, as it is a tax on the legal ownership of the registration and transfer of UK shares, which does not affect the movement of the market and rising of speculation level.

Secondly, the Commission has decided to propose a minimal tax rate, on the one hand, to reduce the risk of relocation, on the other - to guarantee revenue for the EU Member States.

Thirdly, FTT affect banks with higher credit ratings because this category of banks has enough resources, allowing the development of the existing systems to ensure transparent tax collection.

However, the negative impact features are evident:

i. increasing financial transaction costs, market structure may change and develop the business in a speculative manner;

ii. the expected number of transactions and the decline in value can lead to the bank liquidity decrease, wider interest spreads and higher volatility;

iii. revenue to be generated from the toll will not be enough to provide financial support to the banking sector and its restructuring; 
iv. tax would result in the rise of prices of banking services and will affect consumer purchasing power, mainly through retail services;

v. revenues of the state budgets, which imply losses in the capital market, as well as job losses in the banking sector, which could be one of the scenarios implemented in order to reduce the impact on bank customers.

\section{REFERENCES}

[1] De Rato, R. Economic Growth and Financial Market Development: A Strengthening Integration. - Brazil: IMF WP, 3rd International Derivatives and Financial Market Conference, Campos do Jordão, 2007. $28 \mathrm{p}$.

[2] Campbell, J. Y., Froot, K. A. International Experiences with Securities Transaction Taxes. - Chicago: National Bureau of Economic Research, University of Chicago Press, 1994. - 33 p.

[3] Statistical Yearbook of Sweden [Accessed 18.04.2013.]. Available: http://www.scb.se/Grupp/Hitta_statistik/Historisk_statistik/_Dokument/ Statistisk\%20\%C3\%A5rsbok\%2019142001/Statistisk\%20arsbok\%20for\%20Sverige\%201994.pdf

[4] Pay-As-You-Earn and corporate tax receipts from the banking sector, An Official Statistics release [Accessed 15.05.2013.]. Available: http://www.hmrc.gov.uk/statistics/banking/paye-ct-receipts.pdf

[5] SWIFT Standarts [Accessed 12.03.2013.]. Available: http://www.10588.com/pub_web/swift/books/us2m/doc/aif011.htm

[6] Habermeier, K., Kirilenko, A. Securities Transaction Taxes and Financial Markets, IMF Staff Papers Vol. 50. - Washington, D.C.: IMF Working Paper, Fiscal Affairs Department, - 2003. 29 p

[7] Kapoor S., Hillman D., Stephen Spratt Implementing a Currency Transaction Development Levy, Stamp Out Poverty. Oslo: The Norwegian Ministry of Foreign Affairs, 2006. - 48 p.

[8] Keynes, J.M. The General Theory of Employment, Interest and Money. Cambridge: Macmillan Cambridge University Press, for Royal Economic Society, 1936. -472 p.

[9] Wrobel, M.G. Financial Transaction Taxes: The International Experience and the Lesson for Canada. Toronto: Government of Canada Press, 1996. $-6 \mathrm{p}$.

[10] Umlauf, S. R. Transaction Taxes and the Behavior of the Swedish Stock Market. New York: Journal of Financial Economics, 1993. - p. 227-240
[11] EUROSTAT dat a [Accessed 17.05.2013.]. Available: http://epp.eurostat.ec.europa.eu/statistics_explained/index.php/Foreign_ direct_investment_statistics

[12] Mwenda, K.K. Legal Aspects of Financial Services Regulation and the Concept of a Unified Regulator. - Washington, DC: The World Bank, 2006. - 182 p. http://dx.doi.org/10.1596/978-0-8213-6459-8

[13] Nechachby, E., Nilsson, A. Transaction Cost Analysis A-Z: A Step towards Best Execution in the Post-MiFID Landscape. - France: An EDHEC Risk and Asset Management Research Centre Publication, 2012. - $100 \mathrm{p}$.

[14] Scott, J.A., Dunkelberg W.C. Competition for small firm banking business: Bank actions versus market structure, Journal of Banking \& Finance, Volume 34, Issue 11. -Philadelphia: Temple University Press, 2010. - 48. p.

Marija Koḷesnika holds a Master Degree in Business Administration and Professional Qualification of a Manager of Businesses and Organizations at Riga Stradins University (2013). Counting with more than 3 years of work experience in banking, she works as a financial controller at SEB AB, Group Finance division, Trading control. During her active work within the group, Marija has managed to take part in international projects both in Sweden and Latvia. While being a part of financial environment, Marija's special research interests are macroeconomic processes, European economic integration, international monetary integration, financial market and banking sector, as well as corresponding regulation.

E-mail address: Marija.kolesnika@gmail.com

Inna Dovladbekova is a professor of Riga Stradins University (RSU) since 2006. She teaches the courses of Macroeconomics, International Monetary System and International Finances, International Investments, Financial Management, European Economic Integration, EU Monetary and Fiscal Policy at Riga Stradins University, Riga Technical University. She has published 85 works and publications. She is a member of the Doctoral School Council, University of Latvia, Editorial Board of RSU, Editorial Board of Riga Technical University, European Association for Evolutionary Political Economy, New York Academy of Sciences, International Society for the Study of European Ideas (ISSEI). Latest research project and project leadership is Linking Interdisciplinary Integration Studies by broadening the European Network, 2010, Lisbon.

E-mail address: Inna.dovladbekova@rsu.lv

\section{Marija Koḷesṇika, Inna Dovladbekova. Finanšu darījuma nodoklis kā banku sektora regulēšanas politikas instruments Eiropas Savienībā}

Katram darījumam ir savas nodokḷu sekas, vienalga, vai tā būtu iegāde, pārdošana, refinansēešana vai sākotnējais publiskais piedāvājums. Sekmīgai tautsaimniecības atț̄stībai ir nepieciešama valūtas, naudas, kapitāla, vērtspapīru un citu tirgu attīstība. Finanšu tirgus ir svarīgs rādītājs, lai valstī ieplūstu ârvalstu investīijas, jo ar operācijām attīstîtā finanšu tirgū pastāv iespējas minimizēt finanšu risku, kas pastāv pat augsti attīstìtās valstīs.

Saistībā ar ekonomikas un finanšu krīzi aizvien biežāk tiek atzīts, ka finanšu nozarei ir jādod taisnīgāks ieguldījums jeb lielākas iemaksas kopējā budžetā, jo līdz šim šī nozare bija nepietiekami aplikta ar nodokḷiem, ņemot vērā lielākās daḷas finanšu pakalpojumu atbrīvojumu no PVN. Tādẹl finanšu pasaules praksē pastāv tāds jēdziens kā kopējais nodoklis par finanšu darījumiem, kura galvenais mērkịis ir nodrošināt, lai finanšu iestādes dotu savu taisnīgu ieguldījumu iespējamo krīzes izmaksu segšanā, lai izvairītos no finanšu darījumu iekšējā tirgus sadrumstalotības.

Pētījuma mērḳis ir, balstoties uz zinātniskās literatūras analīzi, kā arī statistikas datiem un teorētiskām atziṇām, izpētìt finanšu transakciju nodokḷa ietekmi uz banku darbību Eiropā un piedāvāt iespējas Eiropas Savienības banku regulēšanas sistēmas uzlabošanai. Pirmā nodala raksta ievads un definē finanšsu transakciju nodokli kā banku sektora regulēšanas politikas instrumentu. Otrajā nodạ̄ā tiek veikta teorētiskā analīze, kas sniedz izpratni par finanšu sektora uzraudzības mehānisma būtỉbu. Trešā nodạ̣a atspoguḷo finanšu darījumu nodokḷa darbības analīzi Eiropas Savienībā. Ceturtajā nodaḷā ir noteikti finanšu transakcijas nodokḷa pielietošanas riski un izklāstītas iespējas banku sektora regulējuma uzlabošanai Eiropas Savienībā.

\section{Мария Колесника, Инна Довладбекова. Финансовый налог как инструмент регулирования банковского сектора в ЕС}

У каждой сделки есть свои налоговые последствия, вне зависимости от того, продажа ли это, рефинансирование или первичное публичное размещение. Для успешного развития народного хозяйства необходимо развитие валютного, и денежного рынков, а также рынка капитала и ценных бумаг. Финансовый рынок является важным показателем для привлечения зарубежного капитала, так как с помощью развитого финансового рынка есть возможность снизить финансовый риск, существующий даже в высокоразвитых странах.

В условиях экономического и финансового кризиса все чаще отмечается, что финансовый сектор должен вносить больший вклад в общий бюджет, учитывая, что до сих пор сектор недостаточно облагался налогами, беря во внимание освобождение от уплаты НДС большинства финансовых услуг. Таким образом, в мире финансов существует такое понятие как общий налог на финансовые операции, главной целью которого является обеспечение того, что финансовые учреждения дают свою справедливую долю для покрытия потенциальных затрат от кризиса, и избежать фрагментации внутреннего рынка.

Целью исследования является, анализируя научную литературу, а также статистические и теоретические основы, исследовать влияние финансового налога на развитие банковского бизнеса в Европе и предложить возможности для улучшения банковского регулирования системы Европейского Союза. Раздел I представляет собой введение и демонстрирует необходимость реализации финансового налога на транзакции в качестве инструмента регулирования банковского сектора. Раздел II описывает теоретический анализ политики регулирования финансового сектора. Раздел III иллюстрирует анализ производительности налога на финансовые сделки в рамках Европейского Союза. Раздел IV определяет риски, которые связаны с введением финансового налога, а также излагает возможности для улучшения регулирования банковского сектора в Европейском Союзе. 